Przegląd Prawa Konstytucyjnego

-----ISSN 2082-1212-----

DOI 10.15804/ppk.2019.06.27

-----No. $6(52) / 2019-----$

\title{
Paulina Glejt-Uziębło
}

\section{Selected Issues Regarding the Normative Regulation of the Citizens' Panel in Poland}

Keywords: citizens' panel, public participation, deliberative democracy

Słowa kluczowe: panel obywatelski, partycypacja społeczna, demokracja deliberatywna

\begin{abstract}
The citizens' panel is one of the instruments of deliberative democracy, which has been recently implemented in Poland. Its essence is manifested in the creation of a representative group of residents, which, after acquiring knowledge on a given topic, prepare recommendations constituting a solution to a given problem. The current legal solutions concerning the citizens' panel in Poland are primarily governed by local law. They vary not only in content, but also in legal forms, initiators, methods of appointing experts and even the very concept of the "citizens' panel". This article attempts to show these differences in current Polish regulations. The considerations on the citizens' panel are followed by conclusions de lege ferenda which aim to improve the current legislative solutions.
\end{abstract}

\section{Streszczenie}

\section{Wybrane zagadnienia dotyczące normatywnych regulacji panelu obywatelskiego w Polsce}

Panel obywatelski jest jednym z instrumentów demokracji deliberatywnej, który od niedawna jest wykorzystywany w Polsce. Jego istota przejawia się w utworzeniu reprezen-

1 ORCID ID: 0000-0001-6482-5253, MA, Department of Administrative, Faculty of Law and Administration, Law of the University of Gdansk.E-mail: paulina.glejt-uzieblo@ug.edu.pl. 
tatywnej grupy mieszkańców, która po pozyskaniu wiedzy na dany temat, stworzyłaby rekomendacje stanowiące rozwiązanie określonego problemu. Obecne rozwiązania prawne polskiego panelu obywatelskiego występują są przede wszystkim regulowane aktami prawa miejscowego. Są one zróżnicowane nie tylko co do treści, ale również form prawnych, podmiotów inicjujących, sposobu powoływania ekspertów, a nawet samego pojęcia „panelu obywatelskiego”. W niniejszym opracowaniu podjęto próbę ukazania tych różnić w dotychczasowych polskich regulacjach. Przedstawiono także wnioski de lege ferenda, mające na celu ulepszenie legislacyjnych rozwiązań.

The main purpose of the article is to present selected issues concerning the normative regulation of the institution of the citizens' panel in Polish cities which had attempted to introduce it before the end of 2019. The Polish experience in this regard proves that the creation of acts providing legal bases of the citizens' panel is a multi-layered issue that requires a broad look at this instrument of participatory democracy. At this point, it is worth emphasizing that the citizens' panel is a new mechanism and the cities which have already introduced it are still gathering practical and legislative experience in this respect. Some issues, such as the way of choosing panelists, the age criterion entitling citizens to become panelist, or the method of developing final recommendations are important issues that also require appropriate legal regulation, but the already adopted solutions do not raise much controversy in this regard. That is why the author focuses on key issues important from the perspective of the realization of the essence of this institution, the violation of which can make this instrument a façade tool, such as the legal definition of the term "citizens' panel", the rules of expert selection, as well as the legal and organizational situation of entities responsible for conducting panels.

In the Polish legal system, the citizens' panel, as a form of deliberative democracy ${ }^{2}$, has not been regulated at the statutory level. However, the use of

2 On the citizens' panel as a form of deliberative democracy see more: M. Gerwin, Panele obywatelskie. Przewodnik po demokracji, która dziata, Kraków 2019, p. 15; A. Rytel-Warzocha, Panel obywatelski jako forma partycypacji spotecznej na poziomie lokalnym wświetle doświadczeń Gdańska, [in:] Aktualne problemy prawa Polski i Ukrainy, eds. A. Szmyt, J. Boszycki, J. Stelina, 
this participatory tool is possible due to the assumption that it is a form of public consultations ${ }^{3}$ which are regulated in the Article 5a sec. 1 and sec. 2 of the Act of March 8, 1990 on Municipal Self-Government ${ }^{4}$. This provision states that "in the cases provided for by law and in other matters important for municipalities, consultations with the residents may be carried out on its territory". The term "may", used by the legislator, undoubtedly indicates the optional nature of the implementation of these consultative mechanisms ${ }^{5}$. Undoubtedly, the most experienced Polish city in the field of normative regulations of this form of participatory democracy is Gdańsk ${ }^{6}$. Until now (the end of October 2019), there have been already three citizens' panels organized. Each time new normative acts aimed at better legal regulation of this institution were adopted. In recent years, also other cities became interested in the introduction of citizens' panels, including Lublin, Wrocław, Kraków and Łódź.

When a municipality decides to implement the citizens' panel, its authorities shall adopt a resolution on the rules and procedure for conducting consultations with residents. Such resolution has normative nature and is an act of local law as it contains general and abstract norms which refer to the potential behavior of the municipality residents and to every public consultation to be conducted in future. As a rule, one of the elements of the resolution on public consultations is the indication of its acceptable forms, including the citizens' panel'.

W. Mikołajowicz Iwanow, Gdańsk 2018; R. Marchaj, Samorządowe konsultacje społeczne, Warsaw 2016; P. Glejt-Uziębło, P. Uziębło, Partycypacja w Trójmieście. O prawnej regulacji mechanizmów demokracji semibezpośredniej w Gdańsku, Gdyni i Sopocie, Gdańsk 2018.

3 In my opinion, however, it is possible to treat this mechanism as a separate participatory instrument. M. Brzeski, Problem podstawy prawnej regulacji obywatelskiej inicjatywy uchwatodawczej w statucie jednostki samorzadu terytorialnego, [in:] Partycypacja społeczna w samorzadzie terytorialnym, ed. B. Dolnicki, Warsaw 2014, pp. 394-396.

4 The unified text: Dz.U. 2019, item 1696.

5 A. Rytel-Warzocha, op.cit., p. 75; D. Sześciło, Konsultacje społeczne w gminie w świetle orzecznictwa sądów administracyjnych, "Samorząd Terytorialny” 2014, No. 1-2, p. 27; M. Banat, Konsultacje społeczne w samorzadzie terytorialnym, "Samorząd Terytorialny” 2014, No. 1-2, pp. 13-25.

6 On the origins of the citizens' panel in Gdańsk. M. Gerwin, op.cit., p. 16.

7 The citizens' panel as a form of public consultation is provided, among others, in Gdańsk ( $\$ 14$ of the Resolution No. XVI/494/15 of the City Council of Gdańsk of November 26,2015 on determining the rules and procedure for conducting public consultations with the inhabitants of Gdańsk, The Official Journal of Laws of the Pomeranian Province 2016, item 
In this respect, the aforementioned cities provide similar, though not identical, legal solutions. For example, the $\$ 4$ sec. 1 of the Resolution No. XIX/387/15 of the Wrocław City Council of December 22, 2015 regarding the principles and procedure for conducting consultations with the residents of Wrocław ${ }^{8}$ (hereinafter RMW Resolution No. XIX/387/15) provides for an open catalog of the forms of public consultations by allowing also "other (forms) than those specified in points 1-4 resulting from the specifics of the consultation". A similar solution has been adopted in the respective local legislation in Łódź, which does not explicitly indicate the possibility of conducting a citizens' panel, but leaves the opportunity to use other forms "including those providing the residents of Łódź with a wide access to participate in consultations". Therefore, it can be assumed that although the indicated resolutions introduce the citizens' panel to the local catalog of the instruments of popular participation, they do not regulate any specific issues related to it. The normative approach to the organization of a particular panel is regulated in a variety of ways. Some cities issue normative acts each time they organize the panel (Gdańsk, Lublin, Kraków), while in other cities citizens' panels are based only on the resolution on public consultations and there are no additional acts issued (at the moment Wrocław provides such a solution).

Interestingly, the discrepancy concerns not only whether an additional normative act is issued or not, but also its form. In Lublin, the city's mayor

63 with later amendments, hereinafter Resolution RMG No. XVI/494/15), Lublin ( $\$ 13$ of the Resolution No. 722/XXVIII/2017 of the City Council of Lublin of March 30, 2017 on the mode and principles of conducting public consultations with the residents of the City of Lublin, the Official Journal of Laws of the Lublin Province 2017, item 1793, hereinafter the Resolution RML No. 722/XXVIII/2017), Kraków (\$4 sec. 2 p. 9 of the Resolution No. CXI/2904/18 of the City Council of Kraków of September 26, 2018 on the rules and procedure for conducting consultations with the residents of the Municipal Commune of Kraków and the Kraków Public Benefit Council or non-governmental organizations and entities referred to in the Article 3 sec. 3 of the Act of April 24, 2003 on public benefit activities and volunteering in regard to drafts of local acts in the areas related to the statutory activities of these organizations; the Official Journal of Laws of the Małopolska Province 2018 item 6609, hereinafter: the Resolution RMK No. CXI/2904/18).

8 The Official Journal of Laws of the Lower Silesian Province 2015, item 6197.

$9 \$ 10$ p. 4 of the Regulations of Public Consultations attached to the Announcement of the City Council of Łódź of June 12, 2013; The Official Journal of Laws of the Łódź Province 2013, item 3478 . 
(president) informs about public consultations (including the citizens' panel) in the form of an announcement ${ }^{10}$. This form is also used in Kraków in regard to panels initiated by mayor. However, when the initiative to organize a specific citizens' panel comes from the City Council of Kraków, such initiative takes the form of the Council's resolution ${ }^{11}$. It should be emphasized that according with $\$ 5$ sec. 2 of RMK resolution CXI/2904/18, the City Council of Kraków is only one of several entities authorized to submit an initiative. The citizens' panel is conducted by the Mayor of the City of Kraków ${ }^{12}$. However, in my opinion the Council's resolution is binding so the mayor cannot refuse to hold the panel after its adoption. This results from the regulation provided for in $₫ 6 \mathrm{sec} .1$ of the resolution No. RMK CXI/2904/18, which indicates that "a request for consultation submitted by the entity or entities referred to in $\$ 5 \mathrm{sec} .1 \mathrm{p} .3$ shall be addressed directly to the mayor”. However, the City Council of Kraków is not mentioned among these entities. This thesis seems to be confirmed by the current practice, because as indicated in the Supervisory Decision of the Małopolska Governor of March 5, 201913: "according with the adopted and binding rules of the framework resolution, regardless which municipal authority, the Mayor of the City of Kraków or the City Council of Kraków, proposes to conduct public consultations, and the executive body in the announcement of consultations indicates the forms in which they will be conducted from among all forms of consultations specified in the framework resolution ${ }^{14}$.

In Gdańsk, the detailed regulation of each citizens' panel is determined by a separate regulation of the Mayor of Gdańsk (in case of citizens' panels initiated by the municipal executive body) or by a resolution of the City Council of Gdańsk if the panel is initiated by the Council (like in Kraków). All three panels carried out in Gdańsk so far were conducted on the basis of regulations

\footnotetext{
$10 \$ 7$ of the Resolution RML No. 722/XXVIII/2017.

$11 \$ 5$ sec. 2 of the Resolution RMK No. CXI/2904/18.

$12 \$ 7$ sec. 1 Ibidem.

13 Decision No. WN-II.4131.1.6.2019 of the Governor of Małopolska annulling the Resolution No. VI/93/19 of the City Council of Kraków of January 30, 2019 regarding public consultations on the commemoration of soldiers of the Home Army, The Official Journal of Laws of the Małopolska Province 2019, item 1861.
}

14 Ibidem. 
issued by the Mayor of the City of Gdańsk ${ }^{15}$. It seems that due to the scope of their regulation, which include the rights and obligations of residents (panelists), they should be considered as the acts of local law. This is additionally confirmed by the fact that the legal regulation of consultations also contains a number of provisions relating to the rights of the inhabitants of Gdańsk.

A slightly different solution was adopted in Wrocław, because RMW Resolution No. XIX/387/15 provides that consultations can be ordered either by the City Council of Wrocław or the Mayor of Wrocław ${ }^{16}$. The executive act toward this resolution is the Regulation No. 6221/17 of the Mayor of Wrocław of January 26, 2017 regarding the principles and procedure of conducting consultations with the residents of Wrocław. However, this regulation is an act of internal force, addressed to the employees of the Wrocław City Hall and organizational units of the Wrocław Municipality ${ }^{17}$. Therefore, it has a different character than the regulations of the Mayor of Gdańsk.

A compromise solution in relation to the forms adopted in Gdańsk and Wrocław has been introduced in Łódź, where for the needs of a specific citizens' panel the Mayor issued a regulation, however, as in Wrocław, it was an act containing internally binding regulations ${ }^{18}$.

15 Regulation No. 1548/16 of the Mayor of the City of Gdańsk of October 7, 2016 regarding public consultations in the City of Gdańsk on "How to prepare Gdańsk for heavy rainfall as part of the city's adaptation to climate change" hereinafter referred to as: Regulation No. 1548/16 PMG; https://bip.gdansk.pl/subpages/akty_prawne/pliki/2016/PMG_2016_7_1548.pdf (14.11.2019); Regulation No. 267 of the Mayor of the City of Gdańsk of February 22, 2017 on conducting public consultations in the area of the City of Gdańsk on "How to improve air quality in Gdansk?”, hereinafter referred to as: Regulation No. 267 PMG; https://bip.gdansk. pl/subpages/akty_prawne/pliki/2017/PMG_2017_7_267.pdf (14.11.2019) and the Regulation No. 983/17 of the Mayor of the City of Gdańsk of June 12, 2017 on conducting public consultations in the City of Gdańsk on "How to support civic activity in Gdansk", hereinafter referred to as: Regulation No.983/17 PMG; https://www.gdansk.pl/download/2017-06/91451. $\operatorname{pdf}(14.11 .2019)$.

$16 \$ 5$ sec. 1 of the Resolution RMW No. XIX/387/15.

$17 \int 1$ of the Regulation No. 6221/17 of the Mayor of the City of Wrocław of January 26, 2017 regarding the principles and procedure for conducting consultations with the residents of Wrocław, http://uchwaly.um.wroc.pl/uchwala.aspx?numer=6221/17 (14.11.2019).

18 Regulation No. 2245/VIII/19 of the Mayor of the City of Eódź of October 2, 2019 on the preparation, conduct and implementation of the recommendations of the Citizens' Panel in Łódź "Green in the city", the appointment of the Coordination Committee and the Group on the Łódź Citizens' Panel “Green in the city”, hereinafter referred to as: Regulation 
Considering this, it may be concluded that the regulation of specific solutions constituting the normative basis for conducting a citizens' panel is quite divergent and specific for individual cities. On the one hand, there is Gdańsk where this tool of participation is each time regulated by several legal acts issued $a d h_{o c}^{19}$, on the other hand, there are Wroclaw regulations, which do not even mention the citizens' panel directly as one of the forms of public consultations. The consequence and at the same time the reason for this is the adoption of one of two models of conducting a citizens' panel. The first model assumes the establishment of a steering group responsible for the organization of the panel, which consists of the representatives of municipal authorities as well as independent experts on citizens' panels - such a solution has been adopted, for example in Gdańsk and Łódź. In the second model, on the other hand, the organization of the entire process of the citizens' panel is entrusted to the entities from the outside of the power structure, most often to NGOs. However, it should be noticed that the second solution results in the lack of legal regulations, which provides the entity responsible for conducting the panel with almost full freedom in carrying out the whole procedure. The only restrictions are the resolutions of city councils regarding public consultations and agreements concluded between NGOs and city authorities.

One of the consequences of such discrepancies is the problem with establishing a normative definition of the term "citizens' panel". This is also important due to the different understanding of this concept in the literature and constitutional practice of foreign countries ${ }^{20}$. The author of this article is

No. 2245/VIII/19 PMŁ, https://bip.uml.lodz.pl/files/bip/public/user_upload/VIII_2245. $\operatorname{pdf}(14.11 .2019)$.

19 In addition to the Resolution RMG No. XVI/494/15, a Regulation of the Mayor of the City of Gdańsk is issued together with the annexes constituting its integral part: The Schedule, the Steering Group's Work Mode and the Regulations of Consultations.

20 In the doctrine, the notion of citozens' panel does not raise much controversy. By way of example, we can cite: A. Duda-Jastrzębska, M. Gerwin, M. Jagaciak, M. Nazaruk-Napora, K. Pliszczyńska, Kierunek: Panel obywatelski. Wskazówki dla zainteresowanych, https://stocznia.org.pl/app/uploads/2018/10/Publikacja_Panel-obywatelski.pdf(14.11.2019). However, one should bear in mind the need to distinguish between the citizens' panel and the survey conducted on a specific group of residents, more broadly about the distinction see: P. Glejt-Uziębło, P. Uziębło, op.cit., p. 21; differently: Ł. Młynarkiewicz, Regulacje samorządowe oraz przykłady dobrych praktyk w obszarze konsultacji społecznych w Polsce iza granica, [in:] Partycypacja społeczna w samorzadzie terytorialnym, ed. B. Dolnicki, Warsaw 2014, pp. 811-812. Such 
of the opinion that this concept should be explained in a way that raises no doubts. The Gdańsk legal order defines the citizens' panel as a form of consultations, which is to consult a group of residents ( $\$ 14 \mathrm{sec} .1$ item 6 of the Resolution No. RMG No. XVI/494/15). Prima facie, this definition does not distinguish the citizens' panel from other forms of consultations specified in the same paragraph, such as collecting opinions or proposals in writing and by electronic means or collecting comments in consultation points ( $\$ 14 \mathrm{sec}$. 1 point 3 of the Resolution RMG No. XVI/494/15).

Normative acts of other analyzed cities also do not introduce a proper definition. The resolutions on public consultations adopted in Lublin ${ }^{21}$ or Kraków ${ }^{22}$ did not explain what should be understood by the term "citizens' panel". Due to the fact that the Wrocław regulation does not mention the name of the citizens' panel as a form of public consultations, it obviously does not provide its definition. Only in Gdańsk, the mentioned regulations of the mayor included a more precise definition, treating the citizens' panel as a "consultation with a randomly selected group of residents, which composition reflects the demographic structure of Gdańsk"23, however, it is difficult to agree that this approach fully reflects the essence of this mechanism of public participation. It is also worth mentioning that according to the explanatory memorandum to the Resolution No. VI/187/19 of the City Council of Łódź of March 6,2019 , the citizens' panel is "a technique for making decisions important for

a citizen survey was conducted in Olsztyn, where a group of residents was selected to have the opportunity to comment once and quarterly on a given topic and assess the functioning and development of the city. More on this topic: https://partycypacjaobywatelska.pl/w-olsztynie-powstaje-panel-obywatelski/?fbclid=IwAR0Vuee9D1aAXP6-F83Q4NImT3GwUaAkmPAtqUAGEti8wjE2pKWh7ZY_6hs (14.11.2019).

$21 \$ 13$ sec. 5 of the Resolution RML No. 722/XXVIII/2017.

$22 \$ 4$ sec. 2 p. 9 of the Resolution RMK No. CXI/2904/18.

$23 \$ 1 \mathrm{sec} .2$ of the Regulation of the first consultations, attachment No. 3 to the Regulation No. 1548/16 of the Mayor of the City of Gdańsk of October 7, 2016 (hereinafter referred to as: Regulation of the Consultation attached to the PMG Regulation No. 1548/16); $11 \mathrm{sec}$. 2 of the regulation of second consultations, attachment No. 3 to the Regulation 267 of the Mayor of the City of Gdańsk of February 22, 2017 (hereinafter referred to as: the Regulation of Consultation attached to PMG Regulation No. 267) and $\$ 1$ sec. 2 of the Regulation of third consultations, attachment No. 2 to the Regulation No. 983/17 of the Mayor of the City of Gdańsk of June 12, 2017 (hereinafter referred to as: the Regulation of Consultations attached to the Regulation PMG No. 983/17). 
the local community by residents. The citizens' panel is composed of a randomly selected group of residents' representative for a given community, according to such criteria as age, gender or level of education. The essence of the citizens' panel is to base decisions made by the residents selected to participate in the panel on expert knowledge provided during subsequent panel sessions. The citizens' panel is an element of deliberative democracy, and its most important result are recommendations that are binding on the municipal authorities. According to the assumptions, in order to include these recommendations in the final report from the panel and submit them for implementation, they should be supported by a minimum of $80 \%$ of all panelists' votes. The citizens' panel is the most reliable method of surveying opinions and developing solutions by a representative sample of residents" ${ }^{24}$. Although the description cannot be considered as a legal definition of the citizens' panel, it is worth noting that it includes the main, most important assumptions of this instrument of public participation. Pursuant to $\$ 6$ of the Regulation of the Council of Ministers of June 20, 2002 on the Principles of Legislative Technique, which also applies to acts of local law, their content should be understandable to the recipient. Therefore, the normative definition of the concept of the citizens' panel should be considered as important from the perspective of the certainty of its proper implementation.

However, the question arises about where to get information about the procedure of conducting a citizens' panel in those cities where it has not been normatively regulated. In fact, the only source of knowledge in this regard is the guidelines included in the competition announcements, which aim to select an external entity that will be responsible for conducting the citizens' panel as well as promotional materials prepared by this entity. This is a big problem because the failure to create even a basic legal framework for the organization of the panel may result in considerable, and sometimes even too much freedom in its implementation. Thus, there may be some abuses on the part of both the external entity and the authorities of local government, as they may seek to convince panelists to support views consistent with their activities, regardless of their objectivity.

24 Explanatory note attached to the Resolution No. VI/187/19 of the City Council of Łódź of March 6, 2019. 
This danger is particularly evident at the stage of educational meetings ${ }^{25}$, the purpose of which is to provide panelists with knowledge that will allow them to form their own opinion on a given problem. Substantive meetings with experts in a given field are to serve this purpose. This is a crucial stage of the citizens' panel, because the professional opinions of experts have a significant impact on shaping the views of panel members which will be reflected in the final recommendations that should be considered by the municipal authorities. Therefore, the normative regulation of the method of selecting experts is of particular importance. The first edition of the citizens' panel in Gdańsk provided for the participation of experts in two independent roles. First, obligatorily - there were two experts who were the members of the Steering Group ${ }^{26}$, appointed by the Mayor of the City of Gdańsk. Second, optional - other experts invited to take part in the work of the panel. The second group of experts was appointed by the Steering Group, considering the postulate to ensure representativeness of views on the problem subject to consultations ${ }^{27}$ and at the request of the majority of panelists if financial resources provided for consultations allow for it ${ }^{28}$. The shape of the legal solution can result in the situation that the educational meetings are not organized at all and panelists either rely on their own knowledge or take advantage of the substantive support of experts - members of the Steering Group. However, the latter ones are entities appointed by the municipality executive body so the objections may be raised as to their objectivity. The question also arises whether an expert who is a member of the Steering Group can present his/her opinion to panelists at all, because the Steering Group's competence is only to coordinate the process of consultations, not to participate in panelists' meetings.

The solution adopted in the second edition of the citizens' panel in Gdańsk was inconsistent. Although experts-members of the Steering Group were abandoned and the role of the Steering Group was limited to participation in the work of the panel, it was still closely related to local government author-

25 About educational meetings see more: M. Gerwin, op.cit., p. 19; A. Duda-Jastrzębska, M. Gerwin, M. Jagaciak, M. Nazaruk-Napora, K. Pliszczyńska, op.cit., p. 12.

26 \$5 sec.1 letter c) Regulation No.1548/16 PMG.

$27 \int 9$ Regulation of Consultations attached to the Regulation PMG No. 1548/16.

28 \$ 9 ust. 3. Ibidem. 
ities and decided who was to be invited to cooperate. The lack of consistency was evidenced primarily by the fact that in one paragraph it was stated that "the Steering Group invites experts and the representatives of organizations, institutions, offices and other entities interested in the subject of consultation to participate in the work of the citizens' panel" 29 while in the next paragraph the phrase was used that experts "may be appointed" ${ }^{30}$ which suggested the optional nature of the their participation in the consultation process. It is obvious, however, that according to the teleological interpretation the obligatory nature of the experts' participation in the citizens' panels should be accepted. Otherwise, the essence of the citizens' panels would be violated. In the third regulation, a different legal solution was developed. First of all, the participation of experts in the citizens' panel was obligatory. The right to appoint them was granted to specialists responsible for the organization of the panel appointed by the Steering Group ${ }^{31}$. They were people with extensive knowledge in the field of public participation, not related to the local government bodies. In addition, in the same edition of the citizens' panel for the first time - the expert's tasks were specified in detail, including: panel speech, preparation of a written summary of the speech, as well as answering questions asked by panelists after the speech ${ }^{32}$. As in previous editions, it was possible to appoint an expert proposed by a panelist. In such a situation, the specialists responsible for the organization of the citizens' panel are also responsible for the organization of the experts' speeches and the provision of their opinions ${ }^{33}$.

The respective legal regulations in Łódź have been still under preparation, but it has already been decided that the list of experts and stakeholders presenting their opinions during the citizens' panel shall be approved by the Group for Łódź Citizens' Panel ${ }^{34}$. It is not regulated which entities shall have the right to indicate experts. However, the Chairman of the Group may invite representatives of universities, non-governmental organizations, as well

\footnotetext{
$29 \$ 5$ sec. 3 of the Regulation on Consultations attached to the Regulation PMG No. 267.

$30 \$ 9$ sec. 3 Ibidem.

31 \5 sec. 1 p. 5 of the Regulation No. 983/17 PMG.

$32 \rrbracket 5$ of the Regulation of Consultations attached to the Regulation PMG No. 983/17.

$33 \$ 5$ sec. 4 Ibidem.

$34 \$ 3$ sec. 5 p. 5 of the Regulation No. 2245/VIII/19 PME.
} 
as housing estate councils to participate in the work of the panel as advisors ${ }^{35}$. The expert factor has been therefore enriched with an additional subjective category - advisors.

In Kraków, the selection of a group of experts has been entrusted to an external entity implementing the citizens' panel, which has to consult its decisions with the principal (Mayor of the City of Kraków) ${ }^{36}$. Also, in Lublin the citizens' panel is organized by an external entity. According to the promotional materials prepared for experts, which are available on the website, their tasks include: making a presentation during the panel, providing written materials and summaries of speeches with recommendations, giving opinions on the recommendations developed by panelists and providing all electronic and printed materials for panelists and city residents $\mathrm{s}^{37}$. Experts are appointed by the Group of Coordinators, which consists of two people who are employees of NGOs entrusted with the organization of the citizens' panel.

Solutions which explicitly prohibit members of the organizational group from the city authorities from being experts (Łódź, Gdańsk) should be assessed in plus. It might be also worth considering to provide such restriction in regard to the external entity entrusted with the organization and conduct of citizens' panel. It would then be necessary to normatively define the rules and limits of such cooperation. There may be a number of doubts, such as whether the expertise written for this entity by a certain person as part of previous cooperation affects the objectivity of appointing him/her as an expert in the citizens' panel or not.

The introduction of a fact-checker institution, i.e. a person who verifies the accuracy of information presented during the panel, deserves considerations ${ }^{38}$. This is an additional factor guaranteeing the reliability and objec-

$35 \$ 3$ sec. 4 Ibidem.

36 Point 11 of the announcement of the Mayor of the City of Kraków of the open bid competition as well as recruitment for members of the competition commission for the implementation in the form of entrusting a public task in the field of: activities supporting the development of local communities; https://www.bip.krakow.pl/?news_id=115395\&_ $\mathrm{ga}=2.37273504 .143744365 .1568809913-912764488.1558959138 \& \mathrm{fbclid}=\overline{\mathrm{I}} \mathrm{wAR} 3 \mathrm{~N} 6 \mathrm{FLkr}$ ceRJFSBxd3qztnVSdM6supBdQZbcNP9o51vsQ9V0DUB66QRewA (14.11.2019).

37 https://lublin.eu/mieszkancy/partycypacja/panel-obywatelski/materialy-do-pobrania (14.11.2019).

$38 \$ 5 \mathrm{sec} .5$ of the Regulation of Consultations attached to the Regulation No. 983/17PMG. 
tivity of knowledge provided to panelists. The regulation in Gdańsk uses the phrase "persons", but does not indicate neither their specific number nor the criteria for their appointment. It is only claimed that these persons are indicated by the Steering Group. In Lublin, on the other hand, it was assumed that if necessary, each panelist, facilitator (panel leader) or member of the Steering Group may submit a request to the fact-checker to check the information that appears in the discussion ${ }^{39}$.

There is no doubt that the selection of experts in a given field may prove to be crucial in the context of the final findings included in the recommendations. However, the lack of transparency and the admissibility of manipulation can determine the provisional nature of the citizens' panel.

The essence of the citizens' panel shows that the most important - key role in its implementation is played by panelists. However, it is certain that for both formal and substantive implementation of that instrument of public participation it is necessary to have an entity that will lead its organization. Who will be such an entity strictly depends on the adopted model, because it can be both an external entity and an entity closely associated with the authorities of the local government. In Gdańsk, from the beginning of the implementation of the citizens' panel, such an entity is the Steering Group, which from a normative perspective, during three editions of the panel, has undergone significant modifications. It is worth noting, however, that each time its functioning was regulated in at least three normative acts. The mayor's regulation specified the manner in which he appointed the members of the Group, the annex to the regulation specified the mode of work of the Group, and its tasks were mainly specified in the regulations on consultations. Therefore, the fact that the dispersion of the mentioned issues into several normative acts is unjustified and causes legislative chaos cannot be ignored. In the first edition, the members of the Steering Group were appointed by the Mayor of the City of Gdańsk (five representatives and two external experts) and the City Council (two representatives) ${ }^{40}$. The chairman was appointed by name and surname and not by the function he performed ${ }^{41}$. In the second edition of the panel,

39 https://lublin.eu/mieszkancy/partycypacja/panel-obywatelski/materialy-do-pobrania (14.11.2019).

$40 \$ 5$ sec. 1 of the Regulation No. 1548/16 PMG.

41 \$5 sec. 2 Ibidem. 
on the basis of the Regulation of the Mayor of Gdańsk, ten persons were appointed to the Steering Group, of which eight were associated with the City Hall or the City Council of Gdańsk. What's more, these persons were indicated in the regulation by name. However, it was reserved that some changes could be made to the composition of the Steering Group in justified cases ${ }^{42}$. It should be mentioned that when the chairman of the Steering Group was appointed in the first edition of the panel, doubts arose as to whether the Group members should be appointed by name or the regulation should only specify the positions in the Steering Group without pointing out particular persons by name which seemed to be more reasonable. In my opinion, these conclusions resulted in changes made for the third edition of the panel, in which the composition of the Steering Group was more diverse (three representatives of the Mayor of Gdańsk, two representatives of the City Council of Gdańsk, one representative of the Gdańsk Council of Public Benefit, one representative of the Gdańsk Council of Non-Governmental Organizations and two specialists on panel organization $)^{43}$. There was also a reservation that a representative of the Steering Group could not participate in the panel as an expert and facilitator ${ }^{44}$. As it has been already indicated, undoubtedly, such a regulation increases the objectivity of expert positions.

The main task of the Steering Group is to coordinate consultations ${ }^{45}$. Its other tasks, performed in the first edition of the panel in Gdańsk, included f. ex. the preparation of a partial report on consultations in the form of the collection of opinions and proposals, including a list of all comments submitted by residents ${ }^{46}$, inviting experts and representatives of organizations, institutions, offices and other entities interested in the subject of consultation to participate in the panel ${ }^{47}$, determining the draw procedure and detailed criteria

\footnotetext{
$42 \$ 5$ sec. 1 in relations to sec. 2 of the Regulation No. 267 PMG.

$43 \$ 5$ sec. 1 of the Regulation No. 983/17 PMG.

$44 \$ 5$ sec. 3 Ibidem.

$45 \int 1$ sec. 3 of the Regulation of Consultations attached to the Regulation PMG No. 1548/16, $\$ 1$ ust. 3. of the Regulation of Consultations attached to the Regulation of PMG No. 267.

$46 \$ 4$ sec. 1 of the Regulation of Consultations attached to the Regulation PMG No. 1548/16.

$47 \$ 5$ sec. 3 in relations to $\$ 9 \mathrm{sec}$. 1 of the Regulation of Consultations attached to the Regulation PMG No. 1548/16, $\$ 5$ sec. 3 in relation to $\$ 9 \mathrm{sec} .1$ of the Regulation of Consultations attached to the Regulation PMG No. 267.
} 
regarding demographic structure ${ }^{48}$, defining expert remuneration policy ${ }^{49}$, choosing the voting method ${ }^{50}$. In the second edition of the panel, the Steering Group was also a moderator conducting meetings of the citizens' panel ${ }^{51}$. For the needs of the third edition of the panel in Gdańsk, an open catalog of the Steering Group's tasks was introduced, which included in particular: ensuring the correct procedure of the panel and its credibility, choosing a facilitator, choosing "fact-checkers" and approving the program of panel and expert meetings ${ }^{52}$.

In Łódź, on the other hand, a similar solution to the Gdańsk model from the second panel edition was adopted. By virtue of the regulation of the Mayor of Łódź, the Coordinating Committee for the Łódź Citizens' Panel “Green in the City" has been created, which includes persons indicated by name who are employed at the units related to the Łódź City Hall ${ }^{53}$. In addition to the persons indicated in the mentioned act, the chairman of the Committee may invite other persons to participate in its work ${ }^{54}$. The Committee has been entrusted with three categories of tasks. It is obliged, firstly, to monitor the activities carried out as part of the preparation and conduct of the panel, secondly, to submit a report from the panel with recommendations to the Mayor of Łódź and, thirdly, to coordinate the implementation of the recommendations by the Mayor of Łódź ${ }^{55}$. The regulation appoints one more entity connected to the local government authorities which is responsible for all actions related to the preparation and carrying out the panel - the Group on the Łódź Citizens' Panel "Green in the city". It also includes employees of the organizational units in the City Hall in Łódź, but they are directly related to the topic of the organized panel ${ }^{56}$. The tasks of the Group have been quite broadly defined and relate not only to organizational but also to substantive issues, including the

\footnotetext{
$48 \int 5$ sec. 5 of the Regulation of Consultations attached to the Regulation PMG No. 1548/16.

$49 \int 9$ sec. 2 of the Regulation of Consultations attached to the Regulation PMG No. 1548/16.

$50 \$ 10 \mathrm{sec} .4$ of the Regulation of Consultations attached to the Regulation PMG No. 267.

$51 \$ 5 \mathrm{sec} .6$ of the Regulation of Consultations attached to the Regulation PMG No. 267.

52 \ 3 of the Working mode of the Steering Group, attachment 3 to the Regulation
} No. 983/17 of the Mayor of the City of Gdańsk of June 12, 2017.

$53 \$ 2$ sec. 1 of the Regulation No. 2245/VIII/19 PME.

$54 \$ 2$ sec. 2 of the Regulation No. 2245/VIII/19 PME.

$55 \$ 2$ sec. 3 of the Regulation No. 2245/VIII/19 PME.

$56 \$ 3$ sec. 1 of the Regulation No. 2245/VIII/19 PME. 
development of detailed panel assumptions; substantive supervision over the course of the panel; developing educational materials; preparation of a panel progress report ${ }^{57}$. The solution adopted in Łódź, although it allows to transfer some of the organizational tasks to external entities ${ }^{58}$, has comprehensively divided the tasks necessary for the implementation of the panel between entities officially associated with local government authorities.

A completely different solution has been applied in Lublin. Due to the fact that the organization of the panel has been entirely entrusted to an external entity, the entity organizing the process is the Group of Coordinators appointed from among the employees of this entity. There is no legal regulation determining the way of appointing them. The tasks of the Group of Coordinators include: organization of the speech of an expert appointed by the citizens' panel, establishing contacts with experts and parties between meetings and in special situations - deciding on the compliance of recommendations with the topic of the panel ${ }^{59}$. It is worth noting that the panel is controlled by a monitoring team, which consists of representatives of the Council of Public Benefit Activities of the City of Lublin, which, being an advisory team, consists of representatives of non-governmental organizations and the Office of Public Participation of the City of Lublin ${ }^{60}$. So even if the organization of the panel is transferred to an external entity, there is an element of control from local authorities.

Summing up the considerations regarding the currently existing normative layer of the citizens' panel, several conclusions can be drawn. First of all, in the current legal order there is freedom to regulate the citizens' panel as one of the instruments of public participation. This is an obvious consequence of the municipal self-government and the statutory framework of public consultations. Although, the legal solutions adopted by individual cities are not uniform, it does not necessarily affect their practical dimension. What should be worrying, however, is the lack of regulation or insufficient regulation of

$57 \$ 3$ sec. 5 of the Regulation No. 2245/VIII/19 PMŁ.

$58 \$ 1$ sec. 7 of the Regulation No. 2245/VIII/19 PME.

59 https://lublin.eu/mieszkancy/partycypacja/panel-obywatelski/materialy-do-pobrania (14.11.2019).

60 A. Duda-Jastrzębska, M. Gerwin, M. Jagaciak, M. Nazaruk-Napora, K. Pliszczyńska, op.cit., p. 12 . 
the citizens' panel in the currently binding acts of local law. This may result in using the citizens' panel as a manipulation tool, both by local-government authorities and external entities responsible for the organization of the panel. The author is of the opinion that there should be a general framework at the statutory level that would set the direction for local law. The most important task of the citizens' panel is to obtain an objective, reliable opinion of the inhabitants of a given city. To achieve this, however, it is necessary to create a legal framework guaranteeing objectivity and transparency of activities of all entities involved in the implementation of the citizens' panel. This is particularly important as the organization of this participation instrument is expensive, time consuming and requires a large involvement of many entities, including residents. Any inaccuracies and irregularities will involve a violation of citizens' trust not only in the local authorities, but also in direct democracy itself.

\section{Literature}

Banat M., Konsultacje społeczne w samorzadzie terytorialnym, "Samorząd Terytorialny" 2014, No. 1-2.

Brzeski M., Problem podstawy prawnej regulacji obywatelskiej inicjatywy uchwałodawczej w statucie jednostki samorządu terytorialnego, Partycypacja społeczna w samorządzie terytorialnym, ed. B. Dolnicki, Warsaw 2014.

Glejt-Uziębło P., Uziębło P., Partycypacja w Trójmieście. O prawnej regulacji mechanizmów demokracji semibezpośredniej w Gdańsku, Gdyni i Sopocie, Gdańsk 2018.

Gerwin M., Panele obywatelskie. Przewodnik po demokracji, która działa, Kraków 2019. Marchaj R., Samorządowe konsultacje społeczne, Warsaw 2016.

Młynarkiewicz Ł., Regulacje samorzadowe oraz przykłady dobrych praktyk w obszarze konsultacji społecznych w Polsce i za granica, [in:] Partycypacja społeczna w samorzadzie terytorialnym, ed. B. Dolnicki, Warsaw 2014.

Rytel-Warzocha A., Panel obywatelski jako forma partycypacji społecznej na poziomie lokalnym w świetle doświadczeń Gdańska, [in:] Aktualne problemy prawa Polski i Ukrainy, eds. A. Szmyt, J. Boszycki, J. Stelina, W. Mikołajowicz Iwanow, Gdańsk 2018.

Sześciło D., Konsultacje społeczne w gminie w świetle orzecznictwa sądów administracyjnych, "Samorząd terytorialny" 2014, No. 1-2. 